This item was submitted to Loughborough's Research Repository by the author.

Items in Figshare are protected by copyright, with all rights reserved, unless otherwise indicated.

\title{
Financial reform and financing decisions of listed firms in Zimbabwe
}

PLEASE CITE THE PUBLISHED VERSION

LICENCE

CC BY-NC-ND 4.0

\section{REPOSITORY RECORD}

Mutenheri, Enard, and Christopher J. Green. 2019. "Financial Reform and Financing Decisions of Listed Firms in Zimbabwe". figshare. https://hdl.handle.net/2134/362. 
This item was submitted to Loughborough's Institutional Repository by the author and is made available under the following Creative Commons Licence conditions.

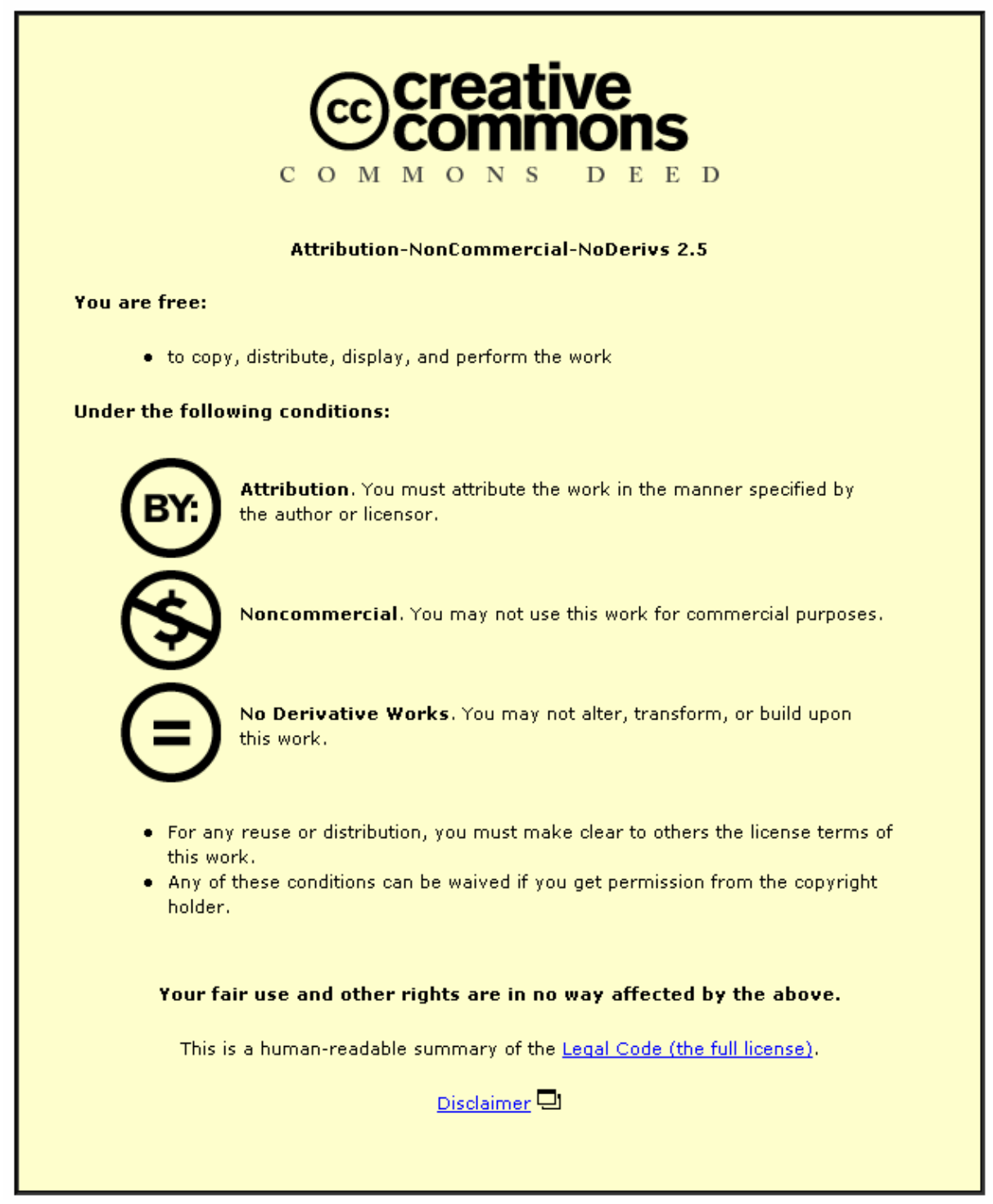

For the full text of this licence, please go to: http://creativecommons.org/licenses/by-nc-nd/2.5/ 
Department of Economics

Economic Research Paper No. 02/5

Financial Reform and Financing

Decisions of Listed Firms in

Zimbabwe

Enard Mutenheri and Christopher J. Green

April 2002

Loughborough

University 
Centre for International, Financial and Economics Research Department of Economics

Loughborough University

Loughborough

Leics., LE11 3TU

UK

Tel: $+44(0) 1509222734$

Fax: + 44 (0) 1509223910

Email: E.J.Pentecost@lboro.ac.uk

Director : $\quad$ Dr Eric J Pentecost

Deputy Director: Professor C J Green

Associate Directors:

Professor Kenneth J Button, George Mason University, USA

Professor Peter Dawkins, University of Melbourne, Australia Professor Robert A Driskill, Vanderbilt University, USA

Professor James Gaisford, University of Calgary, Canada

Professor Andre van Poeck, University of Antwerp, Belgium

Professor Amine Tarazi, University of Limoges, France 
FinanCial Reform And Financing Decisions of Listed Firms in ZimbabWe*

by

\author{
Enard Mutenheri and Christopher J. Green \\ Department of Economics, Loughborough University \\ (Enard Mutenheri is a doctoral candidate at Loughborough University)
}

JEL Classification: G30, G32, O23

Keywords: $\quad$ Zimbabwe, corporate finance, financial reform

\begin{abstract}
We examine the impact of the economic reform programme on the financing choices of Zimbabwean listed companies. Using the published accounts of a sample of companies we show that listed firms rely heavily on external finance, especially short term bank financing. We estimate an eclectic econometric model of firms' capital structure based on key predictions from the theory of finance, augmented by variables aimed at capturing the impact of Zimbabwe's reform programme. The analysis shows that an orthodox model has little explanatory power over firms' capital structure in the pre-reform period, but in the post-reform period it does better. The differences between the pre-reform and post-reform era suggest that the reforms achieved partial success in opening up the capital markets and improving the transparency of firm financing behaviour.
\end{abstract}

correspondence to:

Christopher J. Green: Department of Economics, Loughborough University, Loughborough, Leicestershire, LE11 3TU, United Kingdom

Tel: +44 (0)1509 222711; Fax: +44 (0)1509 223910; E-mail: C.J.Green@lboro.ac.uk

* An earlier draft of this paper was presented at the second annual Finance and Development Research Programme conference, "Development and Business Finance: Policy and Experience in Developing Countries", held at the University of Manchester on April 5-6, 2001; and funded by The Department for International Development (DFID). We thank participants in this conference for their useful comments. Mutenheri's doctoral research is funded by NUFU. Green's contribution forms part of a general research programme on finance and development funded by DFID under the "Finance and Development Research Programme", Contract No. RSC106506. We thank NUFU and DFID for their financial support. The interpretations and conclusions expressed in this paper are entirely our own and should not be attributed in any manner to NUFU or to DFID. 


\section{Introduction}

It is widely agreed that the emergence of a dynamic business sector is an important ingredient in the process of economic development in poorer countries. In this respect, a crucial issue is to understand how firms in developing countries finance their activities and how changes in economic policy impact on these financing decisions. However, as Prasad, Green and Murinde (2001) point out, very little is known about company financing decisions in developing countries. Even the basic facts are by no means agreed. The seminal studies of Singh and Hamid (1992) and Singh (1995) utilized company accounts data covering the largest companies in selected developing countries within the International Finance Corporation (IFC) database. They found that, in comparison with firms in OECD countries, firms in developing countries generally utilize a greater proportion of external funding than internal funding and a greater proportion of equity finance than debt finance. Given that capital markets in developing countries are invariably less well developed than in the industrial countries, especially for equities, these findings were surprising. However, Cobham and Subramaniam (1998) argued that the findings were in part an artefact of Singh and Hamid's methodology and sampling, which they claimed biased the statistics in favour of external funding. Concentrating on a single country (India), but using larger samples of companies and a different methodology based on work by Mayer (1988) and by Corbett and Jenkinson (1997), they argued that external and equity funding ratios in India were substantially lower than claimed by Singh and Hamid. A further study of the accounts of large companies in 10 developing countries using the IFC database by Booth, Aivazian, Demirguc-Kunt and Maksimovic (2001; hereafter: BADM) utilized a methodology proposed by Rajan and Zingales (1995), and found that debt ratios varied substantially across developing countries, but overall were not out of line with comparable data for OECD countries.

A partial reconciliation of the different methodologies employed by previous researchers was discussed by Green, Murinde and Suppakitjarak (2001; hereafter: GMS) who also analysed a large sample of Indian company accounts. Their results broadly confirmed Singh and Hamid's 
findings on external funding ratios but not on debt ratios which, like BADM, they found to be more in line with OECD data. Crucially however, they found that time- and company-averages could conceal considerable changes in company behaviour. In India, there were measurable, significant changes over time in external funding and debt ratios. Many of these could have been related to the economic reform programmes undertaken in India during the late-1980s and early 1990s, but GMS did not test this hypothesis explicitly. It is clearly reasonable to expect that company financing patterns in developing countries will evolve over time as capital markets develop, and in response to any economic reform programmes which may be undertaken. Therefore an essential next step in understanding company financing in developing economies is to examine how far the data are influenced by economic policy changes in different countries.

In this paper we take up the theme of company financing and economic reform, and empirically examine the impact of economic reform programmes on the financing choices of the corporate sector in Zimbabwe. Zimbabwe is of interest for several reasons. First and most basic, Zimbabwe is one of relatively few sub-Saharan African countries with an established corporate sector and a company accounts database which is long-established and of good quality, as we discuss below. Zimbabwe was included in the sample of countries originally considered by Singh and Hamid (1992) and by BADM (2001), and further results for Zimbabwe therefore offer an interesting perspective on previous research. Second, the Zimbabwean corporate sector has evolved through three major and dramatically-different economic regimes: the Unilateral Declaration of Independence (UDI) period (1965-1979), the first decade of independence (19801990) and the Economic Structural Adjustment Programme (ESAP) period that started in December 1991. During the UDI period, international sanctions were imposed on Zimbabwe, forcing the government to adopt an import substitution industrialisation policy. At that time, the only source of external finance for the corporate sector was the domestic financial system. During the first decade of independence the economy was heavily controlled and by the late 1980s there were serious problems of high unemployment levels, inflation rates and a growing budget deficit. As an attempt to address these economic problems, the government adopted an economic reform programme in 1991 with the aim of raising savings, investment and economic 
growth $^{1}$. Thus Zimbabwe has evolved through three very different economic policy regimes and it offers a particularly interesting setting within which to examine questions about economic policy, financial sector growth and company financial behaviour.

In this study we concentrate on evaluating the impact of the economic reform programme begun in 1991. We set up an eclectic but orthodox model of capital structure to test hypotheses about the financing decisions of listed firms in Zimbabwe. We then enlarge this model to include factors which model the possible effects of the economic reform programme. Among these factors we distinguish between the direct channels of policy such as tax rate changes and indirect channels such as improvements in the capital market which flow from broad measures of financial sector reform. Our main hypothesis is that economic reform has helped make financial decisions more transparent and has improved the financing opportunities of the corporate sector in Zimbabwe.

The rest of the paper is organized as follows. Section 2 describes the basic facts about corporate financing in Zimbabwe over the period 1990-99. Section 3 summarizes the main theories of capital structure and sets out the model to be tested. Section 4 contains the results of estimating this model and evaluates the impact of economic reform. Summary and conclusions are presented in section 5 .

\section{The Pattern of Corporate Financing in Zimbabwe}

In this section, we summarise the patterns of corporate financing in Zimbabwe using company accounts data. The main objective of the analysis is to investigate the role of the domestic financial markets, particularly banks and the stock market in financing the Zimbabwean corporate sector in the period 1990-99, just prior to and then following economic reform. The data consist of the annual accounts of 52 non-financial companies listed on the Zimbabwe Stock Exchange from its inception in 1946 through 1999, but excluding companies that were either delisted or taken over. The data were obtained from the annual reports of the individual companies and from various issues of the Zimbabwe Stock Exchange Handbook ${ }^{2}$. 
Table 1 about here

Table 1 shows the gross sources of finance for the 52 sample companies for the period under review. These data were calculated by summing the cash amounts from each source over all companies and then expressing the totals as percentages of gross investment. For 1990-99 as a whole (the rightmost column), the cash amounts were summed over time and then expressed as percentages of the total for 1990-99. This methodology for measuring corporate financial structures is most nearly akin to that proposed by Corbett and Jenkinson (1997) and used by Cobham and Subramaniam (1998) in their study of India.

Since the basic financing choice faced by firms is between internal and external sources, we subdivided the sources accordingly. Internal sources were further subdivided into depreciation and retained profits. External sources were subdivided into long-term and short-term. Longterm finance comprises equity, bonds, bank loans, foreign loans, finance lease, hire purchase, and others. Equity finance is mainly composed of new and rights issues. Bonds consist of preference shares and debentures. Bank loans represent medium and long-term loans provided by the domestic banking sector, mainly commercial banks and the Zimbabwe Development Bank. Foreign loans encompass offshore financing and other foreign loans from institutions such as the International Finance Corporation and the African Development Bank. 'Other' long-term sources consist of loans from domestic non-bank financial institutions, such as pension funds and building societies. Short-term finance comprises bank overdrafts, bank acceptances, trade credit and other short-term sources. 'Other' short-term sources consist of the portion of long-term debt falling due in a year's time and other short-term borrowings not included in the other categories.

For $1990-99$ as a whole, external finance contributed $75 \%$ of total funds and internal finance provided the remaining $25 \%$. Short-term finance accounted for $52 \%$ of external funds with long-term finance contributing the remaining $23 \%$. There were some interesting differences 
among the different components of long-term finance. Equity financing was the most important source of long-term finance at $8 \%$. 'Other' sources of long-term finance (7\%) were the second most important source, and foreign loans contributed 5\% of external funds. Long-term bank loans and bonds were each a very minor component of total external financing. The most important source of short-term financing was from trade credit, which provided about $29 \%$ of the total, with most of the remaining $23 \%$ being provided by banks. Table 1 shows that there were surges in equity financing in 1991 and 1997 when equities contributed as much as 18\% and $21 \%$ (respectively) of total financing. The high contribution of the stock market in these years may be related to policy changes involving the raising of barriers to foreign investors. These changes took place in 1991 at the start of the overall economic reform program, and at the end of 1996 when entry barriers to foreign investors were lowered further. Clearly though, the data suggest that the increased use of the equity market which followed these reforms was very short-lived, a phenomenon that was also documented for India in the 1980s by Cobham and Subramaniam (1998). However, GMS argued that increased use of the equity market in India in the 1990s was more long-lived.

It is interesting to compare the results from our study with other comparable studies. Singh and Hamid (1992) and Singh (1995) examined the financing patterns in Zimbabwe for the period 1980-89 ${ }^{3}$. Exceptionally among the countries they study, their data suggest that internal finance was more important than external finance in Zimbabwe. Our results suggest that Zimbabwean companies relied more heavily on external finance and are therefore more consistent with the other countries studied by Singh and Hamid. The difference between our findings and those of Singh and Hamid are more likely to be due to the different time periods studied than to the different methodologies used, as the Singh method tends to produce a higher share of external financing than ours. Singh and Hamid's data covers the early independence period following the end of UDI when Zimbabwean companies were largely forced to rely on their own resources, whereas our data covers a later period when the economy was more open. This would be consistent with the higher share of external financing that we find. Singh (1995) also reported a much higher share of equity finance in Zimbabwe (43.5\%) than we do (8\%). This 
difference probably is due more to methodological differences, as Singh's method does tend to produce a higher share of equity financing than ours. See inter alia Cobham and Subramaniam (1998) on these methodological points.

\section{A Model of Capital Structure Decisions}

The theory of capital structure has been comprehensively reviewed in several recent papers. Examples include Harris and Raviv (1991) who concentrate primarily on theoretical issues and Prasad, Green, and Murinde (2001), who focus on applications in developing countries. For this reason we do not attempt a comprehensive literature survey in this section. Instead, table 2 summarizes the main variables suggested by theory which are usually thought to influence a company's capital structure. These variables are derived from four of the main strands of literature which can be summarised as follows. First are theories based on asymmetric information as between different stakeholders in the firm, a seminal contribution in this strand being Myers' (1984) pecking order theory; second are agency theories, notably Jensen and Meckling (1976); third are transactions costs theories of the firm, advocated particularly by Williamson (1988); and fourth are extensions of Modigliani and Miller (1963) which argue that differential taxation of corporations and their stakeholders set up incentives for firms to finance their activities in particular ways.

Tables 2 and 3 about here

Table 3 summarizes the main empirical studies with a bearing on the application of these variables in modelling capital structure. The list of references is intended to be illustrative and certainly not comprehensive. Table 3 includes the same firm-specific variables as table 2 . However, it should be emphasized that the corporate tax rate is both a firm-specific variable, depending as it does on each firm's financial position in relation to deductibles such as depreciation, and a policy channel as it also depends on the corporate tax rules in place at any given time. Table 3 includes a further set of 3 macro-economic variables: measures of inflation, 
bank liquidity, and stock market development. These variables are policy- and developmentrelated variables which model the impact of financial development and financial reform on firm behaviour. See BADM (2001) for details. These variables are an important component of our effort to model and understand the impact of the policy reform process in Zimbabwe.

Even the brief summary contained in table 3 underlines the conclusion of Prasad, Green and Murinde (2001) that the empirical literature on corporate capital structure is relatively fragmented. Notwithstanding some of the main theoretical predictions, it is not difficult to obtain a variety of empirical results, some of which are consistent with one or another underlying theory and others which are not consistent with any current theory. In this paper we do not seek to make a new contribution to capital structure theory. Rather we aim to use an eclectic model as a vehicle for arriving at a preliminary evaluation of the impact of economic policy reforms on capital structure decisions. The general empirical model which we estimate can be written using standard notation as:

$$
Y_{j t}=\sum_{i} \beta_{i} X_{i j t}+\varepsilon_{j t}
$$

Here, $Y_{j t}$ is the capital structure measure which we seek to explain, $X_{i j t}$ are $i=1, \ldots, I$ explanatory variables, and $j=1, \ldots, J$ indexes the firms in the sample. The empirical counterparts to these variables are described next.

$Y_{j t}=$ The debt ratio, defined as the ratio of total debt to total assets. This variable can be defined in many different ways. See inter alia Rajan and Zingales (1995) and Green, Murinde and Suppakitjarak (2001). It transpires that the general character of our results are not affected by the definition which is chosen. Therefore, to avoid excessive repetition, we only present results for total debt/total assets, as this is the statistic which is most straightforward to compute on a broadly comparable basis across countries. See Mutenheri (2001) for further details.

The explanatory variables and the expected signs of their coefficients are given as follows: Profitability $(-/+)=$ ratio of operating income to total assets.

Size $(+)=\log$ of total assets.

Cash flow $(+)=$ income attributable to shareholders as a proportion of turnover. 
Dividends $(-)=$ dividend payable as a proportion of operating income. This is included as a supplementary indicator of firm liquidity. Following Shenoy and Koch (1996) we assume that dividends are predetermined in relation to the capital structure decision.

Growth opportunities $(-)=$ percentage change in total assets.

Asset tangibility $(+)=$ ratio of fixed assets to total assets.

Risk $(-)=$ ratio of unexpected income to total assets. Unexpected income is estimated as the absolute values of the residuals from firm-specific regressions of net income before interest and tax on a constant and a time trend.

Corporate tax rate $(+)=$ the ratio of tax paid to operating income.

Inflation $(+)=$ percentage change in consumer price index, an (inverse) measure of real financing costs.

Bank liquidity $(+)=$ the ratio of M2 to GDP, a proxy for bank development.

Stock market development $(+)=$ the ratio of stock market capitalisation to GDP, a proxy for stock market development.

Data for the estimation of the model was collected from the financial statements of 18 companies listed on the Zimbabwe Stock Exchange from 1985 to 1999 . The dataset was then divided into two sub-samples. The first subsample covers 1986-1990, the period of financial repression and this is referred to as equation 1 in the following discussion. Equation 2 covers 1995-1999, corresponding to the post-reform period. Given that reform began in 1991, it was decided to omit the years 1991-94 on the grounds that the impact of reform would be felt only gradually. By 1995, the reforms were mostly in place and firms would have had time to adjust to them and complete a transition to a new equilibrium. We took the view that the sample was too small and the possible adjustments too complex for it to be useful for us to attempt the estimation of a dynamic model to study the transition process itself. However, for completeness we did also estimate a third equation using data from the entire sample period 1986-1999. The model was estimated using both the fixed effects and random effects methods. F tests were used to test for the validity of the fixed effects against the null of pooled OLS, and Hausman tests 
were used to compare the fixed effects and random effects methods. See for example Baltagi (1995) for details.

\section{Empirical Results}

The results from the three regression equations and the relevant diagnostics are presented in table 4. Individual effects are important in all 3 equations. However, the Hausman tests suggest that the random effects method is an adequate parameterisation of equations 1 and 3 , whereas the fixed effects method is required for equation 2 .

Table 4 about here

It is evident that there are substantial differences between the estimated equations for the prereform and post-reform periods. In the pre-reform period, 5 out of 11 variables have the theoretically expected sign, and only one variable (asset tangibility) is significant. Moreover, the sign of the coefficient on tangibility (-) would suggest that firms with more fixed assets tend to borrow less, which is not consistent with the predictions of theory, as suggested by Jensen and Meckling (1976) or Williamson (1988). A possible explanation for this relationship is that the variable may be a proxy for the non-debt tax shields of Zimbabwean firms rather than a measure of asset specificity. In Zimbabwe, a wide range of fixed assets qualify for a Special Initial Allowance which allows 100\% first year depreciation of fixed assets for corporate tax purposes. Companies that acquired fixed assets enjoy a substantial tax shelter, which in turn would reduce the taxable income that could be shielded by debt. Thus, purchases of fixed assets may tend to dominate the tangibility ratio and also the tax shields enjoyed by Zimbabwean firms. Comparing our results for equation 1 with those of BADM, who estimated equations for the total debt ratio for Zimbabwe covering 1980-90, we find a rather broad similarity in that they too find few significant coefficients ${ }^{4}$ and many counter-intuitive signs, such as a negative coefficient on firm size. However, their analysis ends in 1990 before the reform programme got under way. 
The results from equation 2 show that 6 variables have the theoretically expected sign and 5 variables have significant coefficients. Asset tangibility is now positively related to the debt ratio and significant at the $10 \%$ level suggesting that during the post-reform period firms with collateral assets might have better access to the debt market. The change of sign of the tangibility ratio would suggest that during the first decade of independence, access to the debt market was determined by factors not captured by the included variables, whereas after the implementation of the reform program, access to the debt market required collateral assets. The demand for collateral by banks in the post-reform era was such that it led to the establishment of the Venture Capital Company of Zimbabwe and the Indigenous Business Development Centre in order to cater for the financing needs of small- and medium-scale enterprises. This clearly suggests how the reform programme did alter firm behaviour. The other variable which is significant at the $10 \%$ level, is the growth rate which is positively related to firm debt ratios, suggesting that firms with high growth rates use more debt than those with low growth rates. This is contrary to orthodox theory but may be reasonable in the Zimbabwean context. Outsiders in a thin equity market may have more difficulty in recognising a firm's growth opportunities than would more specialized outsiders in banks, leading to a preference of growthoriented firms for more debt.

The tax rate, firm risk and bank liquidity are all significant at the $1 \%$ level, although the first two of these coefficients have counter-theoretical signs. The negative relation between the tax rate and the debt ratio is still consistent with the findings of Krishnan \& Moyer (1996) among others. In Zimbabwe, the relationship could be attributeable to an expectational effect induced by government tax policy. The corporate tax rate was reduced every year from 1980 to 1999 . Companies would therefore have had an incentive to bring forward tax shelters as much as possible to maximise their tax benefits prior to the next cut. Thus, successive tax cuts would be associated with increases in debt ratios as firms expected further tax cuts in the future. The positive coefficient on firm risk could be explained by the fact that firms with risky earnings seek external funds (working capital) to smooth their financing. This is especially plausible in Zimbabwe where we noted in section 3 that on average short-term loans constituted about $52 \%$ 
of firms' external finance. This is consistent with Myers' (1977) argument that short-term debt may be positively related to risk. This result implies that banks play an important role in providing short-term loans to listed firms. The positive coefficient on bank liquidity suggests that the development of banks encourages corporate borrowing. It is particularly striking that this coefficient changes sign between the pre-reform and post-reform periods.

In the third equation, 7 coefficients have the correct sign and 3 are significant. However, given the differences between equations 1 and 2 we do not attach much importance to the pooled estimates as a stable 'model' of the whole period.

Overall, the results from the three equations suggest that the conventional theory of capital structure has relatively little explanatory power in the pre-reform period in the sense that only one variable is significant in the debt equation in the pre-reform period whereas five variables are significant in the post-reform era. Economic regulations by the government in the first decade of independence constrained company financing behaviour. It could mean that during this period, firms were operating at sub-optimal debt ratios implying an inefficient allocation of resources. The structural adjustment programme appears to have changed this behaviour to some extent. Firm size, asset tangibility, tax rates, cash flow, earnings volatility and bank liquidity became important determinants of corporate capital structures in the post-reform era. However, the results from the second equation seem to suggest that firms with high growth rates and fluctuating earnings borrowed more than those with low growth rates and stable earnings, suggesting that the orthodox theories of capital structure may need modification in the context of developing countries like Zimbabwe. Moreover, the results from equation 2 show that profitability, dividends, cash flow, stock market development, and inflation are not significant determinants of corporate financing decisions. This suggests that although the structural adjustment program may have addressed some of the economic problems in Zimbabwe, more still needs to be done and this might explain why company behaviour does not respond to some of the factors suggested in the literature to be of importance for capital structure decisions. 


\section{Summary and conclusions}

In this paper, we first empirically examined the financing pattern of the Zimbabwean corporate sector, using company accounts data. Our major conclusion from this examination is that listed firms rely heavily on external finance, especially short term bank financing. Long-term bank loans make little contribution to financing of the corporate sector. The stock market, on the other hand, does seem to contribute significantly to the financing of the corporate sector. Second, we econometrically investigated key determinants of firms' financial behaviour suggested by the theory of finance, but augmented by variables aimed at capturing the impact of economic reforms and financial development in Zimbabwe. Our main conclusion from this analysis is that these factors have limited power to explain the capital structure of listed firms during the pre-reform period. However in the post-reform period, asset tangibility, tax rates, growth opportunities, earnings volatility and bank liquidity are all significant determinants of capital structure. The differences between the pre-reform and post-reform era suggest that the reforms did achieve a partial success in opening up the capital markets and improving the transparency of firm financing behaviour. 


\section{Footnotes}

1. Details of the reform programme are given in Mutenheri (2001).

2. Data on equity issues were kindly provided by Oliver Lutz of Sagit stockbrokers

3. BADM (2001) used balance sheet data in their study of Zimbabwe and other developing countries, and their statistics are therefore not strictly comparable with ours. In particular, it is difficult to derive information on internal and external financing from balance sheet data. Green, Murinde and Suppakitjarak (2001) discuss this point.

4. BADM's results are hard to interpret because they report fixed and random effects estimates but do not provide any basic diagnostics such as Hausman tests. 


\section{References}

Baltagi, B.H., 1995, Econometric analysis of panel data, New York, Wiley.

Booth, L., Aivazian, V., Demirguc-Kunt, A., Maksimovic, V. (2001) "Capital structures in developing countries", Journal of Finance, Vol. 56, no. 1, pp. 87-130.

Boyle, G.W., and Eckhold, K.R., 1997, "Capital structure choice and financial market liberalisation: Evidence from New Zealand", Applied Financial Economic, Vol. 7, pp. 427-437.

Bradley, M., Jarrell, G. and Kim, E.H., 1984, "On the existence of an optimal capital structure: theory and evidence", Journal of Finance, Vol. 39, pp. 857- 878.

Cobham, D. and Subramaniam, R., 1998, "Corporate finance in developing countries: new evidence for India", World Development, Vol. 26, No. 6, pp. 1033-1047.

Corbett, J. and Jenkinson, T., 1997, "How is investment financed? A study of Germany, Japan, the United Kingdom and the United States", Manchester School, Vol. 65, Supplement, pp. 69-93.

DeAngelo, H. and Masulis, R.W., 1980, “Optimal capital structure under corporate and personal taxation", Journal of Financial Economics, Vol. 8, pp. 3-29.

Demirguc-Kunt, A. and Maksimovic, V., 1996, "Stock market development and financing choices of firms", The World Bank Economic Review, Vol. 10, pp. 341-369.

Firth, M., 1995, "The impact of institutional stockholders and managerial interests on the capital structure of firms", Managerial and Decision Economics, Vol.16, pp. 167-175.

Green, C.J., Murinde, V. and Suppakitjarak, J., 2001, "Corporate financial structures in India", Finance and Development Research Programme Working Paper, forthcoming.

Harris, M. and Raviv, A., 1991, "The theory of capital structure," Journal of Finance, Vol. 49, pp. 297-355.

Homaifar, G., Zietz, J., and Benkato, O., 1994, "An empirical model of capital structure, some new evidence", Journal of Business Finance and Accounting, Vol. 21, pp. 1-14.

Jensen, M.C. (1986), “Agency Costs of Free Cash Flow, Corporate Finance and Take-overs“, American Economic Review, Vol. 76, pp. 323-339. 
Jensen, M.C. and Meckling, W.H., 1976, “Theory of the firm: Managerial behaviour, agency costs and ownership structure", Journal of Financial Economics, Vol. 3, pp. 305- 360.

Jensen, M.C. and Meckling, W.H., 1992, "Specific and General Knowledge, and Organizational Structure", in L. Werin and H. Wijkander (eds.), Contract Economics, Massachusetts, Blackwell.

Kim, W.S. and Sorensen, E.H., 1986, "Evidence on the Impact of the Agency Costs of Debt in Corporate Debt Policy", Journal of Financial and Quantitative Analysis, Vol. 21, pp. 131-144.

Krishnan,V.S. and Moyer, R.C., 1996, "Determinants of capital structure: An empirical analysis of firms in industrialised countries", Managerial Finance, Vol. 22, p39-55.

Lowe, J., Naughton, T. and Taylor, P., 1994, "The Impact of Corporate Strategy on the Capital Structure of Australian Companies", Managerial and Decision Economics, Vol. 15, pp. 245-257.

Mackie-Mason, J. (1990), "Do Firms Care Who Provides Their Financing?", in R. G. Hubbard (ed), Asymmetric Information, Corporate Finance and Investment, Chicago and London: University of Chicago Press.

Mayer, C., 1988, "New issues in corporate finance", European Economic Review, Vol. 32, pp. 1167- 1189.

Modigliani, F. and Miller, M.H., 1963, "Corporate income taxes and the cost of capital: A correction", American Economic Review, Vol. 53, pp. 433- 443.

Mutenheri, E., 2001, "Financing decisions of listed firms in Zimbabwe", mimeo.

Myers, S.C., 1977, "Determinants of corporate borrowing”, Journal of Financial Economics, Vol. 5, pp. 147-175.

Myers, S.C., 1984, “The capital structure puzzle”, Journal of Finance, Vol. 34, pp. 575- 592.

Prasad, S., Green, C.J., and Murinde, V., 2001, "Company financing, capital structure, and ownership", SUERF Study No 12, Vienna, SUERF.

Rajan, R. and Zingales, L., 1995, "What do we know about capital structure? Some evidence from international data", Journal of Finance, Vol. 50, pp. 1421- 1460.

Saa-Requejo, J., 1996, "Financing decisions: Lessons from the Spanish experience”, Vol. 25, pp. 44-56.

Shenoy, C. and Koch, P.D., 1996, “The firm's leverage-cash flow relationship”, Journal of Empirical Finance, Vol. 2, pp. 307-331. 
Singh, A., 1995, "Corporate financial patterns in industrialising economies: a comparative study", IFC Technical Paper No. 2, Washington D.C., International Finance Corporation.

Singh, A. and Hamid, J., 1992, "Corporate financial structures in developing countries", IFC Technical Paper No. 1, Washington D.C., International Finance Corporation.

Thies, C.F. and Klock, M.S., 1992, "Determinants of Capital Structure”, Review of Financial Economics, Vol. 1, pp. 40-52.

Titman, S. and Wessels, R., 1988, “The determinants of capital structure choice", Journal of Finance, Vol. 43, pp. 1-19.

Williamson, O.E., 1988, "Corporate finance and corporate governance", Journal of Finance, Vol. 43, pp. 567-591.

Wiwattanakantang, Y., 1999, “An Empirical study on the determinants of the structure of Thai Firms", Pacific-basin Finance Journal, Vol.7, pp. 371-403. 
Table 1. Zimbabwe: Listed Companies' Gross Sources of Finance, 1990-99 (52 companies; in per-cent of total financing)

\begin{tabular}{|l|c|c|c|c|c|c|c|c|c|c|c|}
\hline & $\mathbf{1 9 9 0}$ & $\mathbf{1 9 9 1}$ & $\mathbf{1 9 9 2}$ & $\mathbf{1 9 9 3}$ & $\mathbf{1 9 9 4}$ & $\mathbf{1 9 9 5}$ & $\mathbf{1 9 9 6}$ & $\mathbf{1 9 9 7}$ & $\mathbf{1 9 9 8}$ & $\mathbf{1 9 9 9}$ & $\mathbf{1 9 9 0 - 9 9}$ \\
\hline & & & & & & & & & & & \\
\hline Internal Finance & $\mathbf{1 6 . 3}$ & $\mathbf{1 7 . 8}$ & $\mathbf{1 7 . 7}$ & $\mathbf{1 9 . 7}$ & $\mathbf{2 8 . 7}$ & $\mathbf{2 2 . 9}$ & $\mathbf{1 9 . 9}$ & $\mathbf{1 7 . 9}$ & $\mathbf{2 5 . 3}$ & $\mathbf{3 2 . 8}$ & $\mathbf{2 4 . 6}$ \\
\hline Retained Income & 9.4 & 12.0 & 10.9 & 12.9 & 22.0 & 14.1 & 12.0 & 10.9 & 18.5 & 25.8 & 17.5 \\
\hline Depreciation & 6.9 & 5.8 & 6.8 & 6.7 & 6.7 & 8.8 & 7.9 & 7.0 & 6.9 & 7.0 & 7.1 \\
\hline & & & & & & & & & & & \\
\hline External Finance & $\mathbf{8 3 . 7}$ & $\mathbf{8 2 . 2}$ & $\mathbf{8 2 . 3}$ & $\mathbf{8 0 . 3}$ & $\mathbf{7 1 . 3}$ & $\mathbf{7 7 . 1}$ & $\mathbf{8 0 . 1}$ & $\mathbf{8 2 . 1}$ & $\mathbf{7 4 . 7}$ & $\mathbf{6 7 . 2}$ & $\mathbf{7 5 . 4}$ \\
\hline & & & & & & & & & & & \\
\hline Long-term Finance & $\mathbf{2 9 . 8}$ & $\mathbf{3 7 . 4}$ & $\mathbf{3 2 . 0}$ & $\mathbf{2 6 . 4}$ & $\mathbf{2 4 . 9}$ & $\mathbf{2 9 . 3}$ & $\mathbf{3 0 . 8}$ & $\mathbf{3 4 . 6}$ & $\mathbf{1 5 . 4}$ & $\mathbf{1 4 . 9}$ & $\mathbf{2 3 . 6}$ \\
\hline Equity Finance & 8.8 & 17.6 & 6.4 & 7.9 & 7.0 & 7.6 & 9.5 & 20.5 & 2.7 & 2.8 & 7.8 \\
\hline Bonds & 0.9 & 2.7 & 1.0 & 0.2 & 0.2 & 1.6 & 0.7 & 1.8 & 1.1 & 0.7 & 1.0 \\
\hline Bank Loans & 2.6 & 2.0 & 1.3 & 2.1 & 0.9 & 0.3 & 1.7 & 1.8 & 1.1 & 0.5 & 1.2 \\
\hline Foreign Loans & 3.0 & 2.7 & 2.1 & 3.2 & 11.9 & 10.3 & 8.9 & 4.7 & 2.0 & 3.8 & 5.0 \\
\hline Finance Lease & 0 & 0 & 0 & 0 & 0 & 1.3 & 1.0 & 0.4 & 2.4 & 0.4 & 0.9 \\
\hline Hire Purchase & 0.1 & 0 & 0 & 0 & 0 & 0 & 1.0 & 0 & 2.0 & 0.3 & 0.6 \\
\hline Other sources & 14.4 & 12.4 & 21.2 & 12.9 & 4.8 & 8.2 & 7.9 & 5.3 & 4.1 & 6.3 & 7.2 \\
\hline & & & & & & & & & & & \\
\hline Short-term Finance & $\mathbf{5 3 . 9}$ & $\mathbf{4 4 . 8}$ & $\mathbf{5 0 . 3}$ & $\mathbf{5 4 . 0}$ & $\mathbf{4 6 . 4}$ & $\mathbf{4 7 . 8}$ & $\mathbf{4 9 . 3}$ & $\mathbf{4 7 . 6}$ & $\mathbf{5 9 . 3}$ & $\mathbf{5 2 . 3}$ & $\mathbf{5 1 . 8}$ \\
\hline Bank Overdraft & 8.5 & 8.6 & 14.7 & 8.8 & 8.8 & 8.7 & 6.2 & 7.4 & 11.5 & 9.5 & 9.3 \\
\hline Bank Acceptance & 2.6 & 1.3 & 1.7 & 2.6 & 2.2 & 1.2 & 3.2 & 2.7 & 4.1 & 1.3 & 2.4 \\
\hline Trade Credit & 27.3 & 18.5 & 24.1 & 27.1 & 22.7 & 23.7 & 25.7 & 23.9 & 35.5 & 29.3 & 27.8 \\
\hline Other S/Term Sources & 15.4 & 16.4 & 9.8 & 15.5 & 12.7 & 14.3 & 14.2 & 13.6 & 8.2 & 12.2 & 12.2 \\
\hline
\end{tabular}

Table 2. Theoretical Determinants of Debt Ratios.

\begin{tabular}{|c|c|c|c|c|}
\hline Firm Factor & $\begin{array}{l}\text { Impact on } \\
\text { Leverage }\end{array}$ & Reason & Model & Reference \\
\hline \multirow[t]{2}{*}{ Profitability } & Positive & Pecking order hypothesis & Asymmetric information & Myers (1984) \\
\hline & Negative & Enhances firm's ability to borrow & & \\
\hline Size & Positive & Less vulnerable to bankruptcy & Asymmetric information & Myers (1984) \\
\hline Free Cash Flow & Positive & Pre-commitment & Agency & Jensen(1986) \\
\hline Growth opportunities & Negative & Under-investment problem & Agency & Myers (1977) \\
\hline \multirow[t]{2}{*}{ Asset Tangibility } & Positive & Collaterals & Agency & Jensen and Meckling (1976) \\
\hline & Positive & Reduces bankruptcy costs & Transaction costs & Williamson (1988) \\
\hline Risk & Negative & Bankruptcy costs & Transaction costs & Myers (1977) \\
\hline Corporate tax rate & Positive & Reduces corporate tax burden & Taxation & Modgliani \& Miller (1963) \\
\hline Non-debt tax shields & Negative & Shields firm tax & Taxation & DeAngelo \& Masulis (1980) \\
\hline Asset diversification & Positive & Reduces risk & & \\
\hline
\end{tabular}


Table 3. Summary of Empirical Studies

\begin{tabular}{|c|c|c|c|c|}
\hline \multirow[t]{2}{*}{ Factor } & \multirow{2}{*}{$\begin{array}{c}\text { Expected } \\
\text { Sign }\end{array}$} & \multirow[t]{2}{*}{ Theoretical Reference } & \multicolumn{2}{|c|}{ Empirical Evidence } \\
\hline & & & Positive & Negative \\
\hline Profitability & $\begin{array}{c}\text { Positive } \\
\text { Negative }\end{array}$ & $\begin{array}{l}\text { Rajan \&Zingales (1995) } \\
\text { Myers(1984) }\end{array}$ & & $\begin{array}{l}\text { Titman \& Wissels(1988) } \\
\text { Jensen \& Meckling (1992) } \\
\end{array}$ \\
\hline Size & Positive & Kim \& Sorensen (1986) & \begin{tabular}{|l|} 
Firth (1995) \\
Hussain (1997) \\
\end{tabular} & Titman \& Wissels(1988) \\
\hline Free cash flow & Positive & Jensen (1986) & Shenoy and Koch (1996) & $\begin{array}{l}\text { Lowe, Naughton, \& Taylor } \\
\text { (1994) }\end{array}$ \\
\hline Growth opportunities & Negative & \begin{tabular}{|l|} 
Myers $(1977)$ \\
Jensen (1986) \\
\end{tabular} & Krishnan \& Moyer (1996) & $\begin{array}{l}\text { Homaifar, Zietz \& Benkato } \\
(1994)\end{array}$ \\
\hline Asset tangibility & Positive & Myers (1977) & $\begin{array}{l}\text { Jensen \& Meckling (1992) } \\
\text { Thies \& Klock (1992) }\end{array}$ & \\
\hline Risk & Negative & Bradley, Jarrell \& Kim(1984) & & $\begin{array}{l}\text { Mackie-Mason (1990) } \\
\text { Saa-Requejo(1996) }\end{array}$ \\
\hline Corporate tax rate & Positive & Modgliani and Miller (1963) & $\begin{array}{l}\text { Homaifar, Zietz \& Benkato } \\
(1994)\end{array}$ & Krishnan \& Moyer (1996) \\
\hline Non-debt tax shields & Negative & DeAngelo \& Masulis (1980) & Boyle \& Eckhold (1997) & Wiwattanakantang (1999) \\
\hline Inflation & Positive & BADM (2001) & & BADM (2001) \\
\hline Bank liquidity & Positive & Dermirguc-Kunt \& Maksimovic(1996) & BADM (2001) & \\
\hline $\begin{array}{l}\text { Stock market } \\
\text { development }\end{array}$ & Negative & Dermirguc-Kunt \& Maksimovic(1996) & & BADM (2001) \\
\hline
\end{tabular}

BADM: Booth, Aivazian, Demirguc-Kunt, \& Maksimovic (2001) 
Table 4. Regression Results

\begin{tabular}{|c|c|c|c|c|}
\hline & & $\begin{array}{c}\text { Pre-reform } \\
(1986-90)\end{array}$ & $\begin{array}{c}\text { Post-reform } \\
(1995-99)\end{array}$ & $\begin{array}{c}\text { Pooled } \\
(1986-99)\end{array}$ \\
\hline Explanatory variable & $\begin{array}{l}\text { Expected } \\
\text { sign }\end{array}$ & Random Effects & Fixed Effects & Random Effects \\
\hline \multirow[t]{2}{*}{ Profitability } & $-/+$ & 0.038 & 0.238 & -0.046 \\
\hline & & $(0.290)$ & $(1.433)$ & $(0.755)$ \\
\hline \multirow[t]{2}{*}{ Size } & + & 2.911 & 5.450 & 3.595 \\
\hline & & $(0.463)$ & $(0.803)$ & $(2.493)^{* *}$ \\
\hline \multirow[t]{2}{*}{ Cash flow } & + & -0.028 & -0.300 & -0.027 \\
\hline & & $(0.423)$ & $(1.177)$ & $(0.585)$ \\
\hline \multirow[t]{2}{*}{ Dividends } & - & 0.074 & -0.045 & -0.015 \\
\hline & & $(1.337)$ & $(0.451)$ & $(0.423)$ \\
\hline \multirow{2}{*}{ Growth opportunities } & - & 0.010 & 0.065 & -0.005 \\
\hline & & $(0.256)$ & $(1.888)^{*}$ & $(0.263)$ \\
\hline \multirow[t]{2}{*}{ Asset tangibility } & + & -0.202 & 0.234 & 0.032 \\
\hline & & $(2.305)^{* *}$ & $(1.884)^{*}$ & $(0.682)$ \\
\hline \multirow[t]{2}{*}{ Firm risk } & - & -0.012 & 0.242 & 0.066 \\
\hline & & $(0.207)$ & $(2.578)^{* * *}$ & $(2.146)^{* *}$ \\
\hline \multirow[t]{2}{*}{ Corporate tax rate } & + & -0.034 & -0.294 & -0.027 \\
\hline & & $(0.639)$ & $(3.322)^{* * *}$ & $(0.854)$ \\
\hline \multirow[t]{2}{*}{ Inflation } & + & 0.247 & -0.100 & -0.029 \\
\hline & & $(0.622)$ & $(1.047)$ & $(0.530)$ \\
\hline \multirow[t]{2}{*}{ Bank liquidity } & + & -1.953 & 0.964 & 0.488 \\
\hline & & $(0.552)$ & $(2.795)^{* * *}$ & $(2.378)^{* *}$ \\
\hline \multirow[t]{2}{*}{ Stock market } & - & -0.217 & -0.004 & -0.010 \\
\hline & & $(1.079)$ & $(0.059)$ & $(0.220)$ \\
\hline \multicolumn{5}{|l|}{ Specification Tests } \\
\hline Test for company effects & & $\mathrm{F}(17,61)=15.7$ & $\mathrm{~F}(17,61)=5.0$ & $\mathrm{~F}(17,151)=5.5$ \\
\hline Hausman test & & $\chi^{2}(11)=8.9$ & $\chi^{2}(11)=20.9$ & $\chi^{2}(11)=16.1$ \\
\hline
\end{tabular}

Notes

$\mathrm{T}$ statistics are in parentheses. Significance shown by: * $10 \%$, level; ** $5 \%$ level; *** $1 \%$ level

Critical values at $5 \%$ level for: $\mathrm{F}(17,61)=1.84 ; \quad \mathrm{F}(17,151)=1.67 ; \quad \chi^{2}(11)=19.7$ 